\title{
Endoplasmic reticulum stress and organoids
}

\author{
Rashedul Alam ${ }^{1^{*}}$, Mohammad Mamun Ur Rashid $^{1^{*}}$, Mohammad Fazlul Kabir ${ }^{2}$, Hyung-Ryong Kim ${ }^{3}$ \\ ${ }^{1}$ Department of Pharmacology and Institute of New Drug Development, Jeonbuk National University Medical School, Jeonju, Korea \\ ${ }^{2}$ Department of Biology, Georgia State University, Atlanta, GA, USA \\ ${ }^{3}$ College of Dentistry and Institute of Tissue Regeneration Engineering, Dankook University, Cheonan, Korea
}

Received: December 15, 2020

Accepted: January 15, 2021

Correspondence to:

Hyung-Ryong Kim, DDS, PhD

College of Dentistry and Institute of

Tissue Regeneration Engineering

(ITREN), Dankook University, 119

Dandae-ro, Dongnam-gu, Cheonan

31116, Korea

E-mail: hrkimdp@gmail.com

*These authors contributed equally.

\begin{abstract}
Organoids represent an advanced tool in cell biology and have redefined biomedical research. Organoids are ideal for studies of biological processes, pharmacological studies, and therapeutic research to imitate pathological processes and preserve genetic integrity. The endoplasmic reticulum (ER) is the central organelle responsible for protein folding, post-translational adaptations, and membrane and luminal protein transportation. ER stress is a disorder influenced by a range of physiological and pathological causes, such as nutrient deficiency, impaired glycosylation, calcium depletion, oxidative stress, DNA damage, and energy disruption. Disturbance of the ER environment triggers aggregation of unfolded/misfolded proteins, accelerating ER stress. The unfolded protein response (UPR) is a transduction mechanism that activates cells in response to ER stress to restore ER homeostasis, altering cancer development and progression. However, the mechanisms through which sustained and unresolved UPR signaling triggers a switch from pro-survival to pro-death pathways remain unclear. Immutable and environmental stimuli that modify protein homeostasis are often incorporated into tumor cells, thereby generating ER stress. Herein, we discuss challenges and advances in fundamental and clinical cancer studies on ER stress. Additionally, current trends in organoid technology are summarized to fill the gap in our knowledge of the relationship between cancer and ER stress, with the UPR representing a future tool for investigating drug response screening and potentially revolutionizing the workflow of new cancer drug development.
\end{abstract}

Keywords: Endoplasmic reticulum stress; Unfolded protein response; Organoid; Drug development; Drug resistance

\section{Introduction}

Organoids are characterized by three-dimensional (3D) epithelial primary cell cultures that develop and self-organize from stem cells via cell sorting and spatially restricted descendant commitment, similar to the in vivo process [1]. Embryonic stem cells or induced pluripotent stem cells (known colloquially as pluripotent stem cells or PSCs) and adult stem cells (ASCs) can construct organoid cultures [2]. Organoids in suspensions often exhibit circular or irregular shapes or are embedded in various types of matrices [3]. In vitro organoids have several benefits in human physiological studies and disorder simulations, preclinical studies, and cell culture systems. Furthermore, an organoid can mature and advance in all directions in 3D culture system, enabling the visualization of organ growth and genetic variability in animal models [4]. Different types of growth factors and small molecules are used during the organoid culture process, often in a tissue-specific manner, to control the signaling pathways necessary for organoid

Copyright (C) 2021 The Organoid Society

This is an Open Access article distributed under the terms of the Creative Commons Attribution Non-Commercial License (http://creativecommons.org/licenses/by$\mathrm{nc} / 4.0 /)$ which permits unrestricted non-commercial use, distribution, and reproduction in any medium, provided the original work is properly cited. 
self-renewal, proliferation, and differentiation. The first strategy is focused on the division of PSCs, which assemble themselves to form organoids unique to the tissue, such as the optic cup, brain, kidney, prostate, lung, pancreas, and intestine [5-9]. Organoid model-based research for disease analysis is currently being conducted for cancer, malignancy, developmental disabilities, and chronic infectious diseases.

The endoplasmic reticulum (ER) is an organelle closely involved in controlling protein synthesis in the cellular compartment. It detects misfolded proteins and restores protein homeostasis via protein folding. Defective protein folding within the ER and during pathological stress conditions leads to perturbations in ER homeostasis. This imbalance in ER homeostasis activates an ensemble of transcriptional programs known as the unfolded protein response (UPR) [10,11]. Three ER membrane-embedded sensors regulate the UPR: double-stranded RNA-activated protein kinase-like ER kinase (PERK, also known as EIF2aK3), inositol requiring enzyme $1 \alpha$ (IRE1 $\alpha$, also known as ERN1), and activating transcription factor 6 (ATF6). The UPR attenuates protein load on the ER through a temporal shutdown of protein translation along with a complex program of gene transcription mediated by distinct transducers such as ATF4 (for PERK), cleaved ATF6 (for ATF6), and spliced XBP1 (sXBP1; for IRE1 $\alpha$ ) [12]. These factors directly trigger the transcription of chaperones or proteins participating in redox homeostasis, protein secretion, lipid/fatty acid synthesis, or cell death. However, during ER stress, glucose regulatory protein 78 (GRP78) dissociates from each of these sensors, allowing the activation of various adaptive signaling pathways in a collective effort to relieve ER stress [13].

UPR dysfunction is implicated in many human diseases, including cancer, diabetes, neurodegeneration, ischemia, and infectious diseases. Over the past decade, several pieces of evidence have suggested that the three arms of the UPR are highly activated in conditions characteristic of the tumor environment, such as hypoxic, acidic, and nutrient-deprived milieus [14]. Although sustained UPR activation is linked to the induction of apoptotic signaling, cancer cells can bypass this apoptotic switch and exploit the UPR to promote proliferation, metastasis, and chemoresistance in several cancer types. However, unresolved ER stress can lead to excessive UPR activation, which ultimately results in programmed cell death $[15]$.

Thus, dysfunction of the ER stress response has been found to be correlated with various intracellular physiological conditions, and unsurprisingly, with dysregulation of the innate and adaptive immune response. Recent research has shown that UPR sensors control the growth, differentiation, activation, and development of cytokines, as well as apoptosis in several types of immune cells, including T cells, B cells, dendritic cells, macrophages, and myeloid-derived suppressor cells [16]. As such, the emerging role of UPR effectors in the management of a variety of immune disorders, including cancer, has focused researchers' attention on targeting UPRs [17]. In many cases, ER stress measurements in two- dimensional (2D) cell culture methods may fail to connect with the findings of animal investigations. Moreover, in cancer cells, numerous gene mutations have been found to enhance cancer progression by causing misfolding and accumulation of unfolded proteins in the ER lumen. In these conditions, organoid models will be handy for investigating cancer and ER stress-related diseases. In this paper, we review the significance of organoid research on ER stress regulation, which has yielded several physiological findings of preclinical importance, and describe the potential value of organoids as a method for drug development.

\section{Applications of organoids to explore cancer and the UPR}

Over the past decade, clinical trials in the field of cancer biology have generally relied on $2 \mathrm{D}$ cancer cell lines in vitro and on animal models in vivo. These techniques have yielded enormous insights, but after numerous passages, cell lines may not accurately represent the pathophysiology of the original parent tumors [18]. In contrast, organoid technologies make bridges between $2 \mathrm{D}$ cell line cultures and in vivo physiological and pathophysiological models, facilitating recapitulation of self-renewal, differentiation, and pathologies responsible for human diseases, including infectious diseases, genetic abnormalities, and cancers [19]. Tumor organoids can now be used to identify core molecular mechanisms of ER stress that may be correlated with cancer cell survival, proliferation, and tumor progression, and facilitate drug testing in vitro. Furthermore, organoids can be engineered with tumorigenic alterations to model cancer initiation, evolution, initiating cells, and oncogenic pathogens; the ability to incorporate these processes is thought to be a closer representation of human disease. In organoid research, stem cells have presented a major breakthrough in terms of understanding cancer progression, drug resistance, and recurrence under different stress conditions, and the stemness of stem cells is regulated by the UPR $[20,21]$.

ER stress has generated immense interest in studying human cancerous organs' physiology since the UPR plays an essential role in regulating stem cell differentiation, and targeting the UPR may therefore be a therapeutic strategy. UPR is activated in tumor cells to alleviate ER stress by expansion of the ER lumen, transcription of ER-resident chaperones for protein folding, degradation of misfolded/unfolded proteins, and lipid production needed for 
rapid proliferation. Although these mechanisms allow cells to adapt to exist in an oxygen- and nutrient-deprived environment, chronic or unresolved ER stress can nonetheless lead to apoptosis. The evaluation of the degree and duration of the UPR activation by sensors of ER stress (IRE1 $\alpha$, PERK, and ATF6) seems critical for cell death or survival [22]. However, using tumor organoids could shift this workflow from a linear to high-throughput matrix process. At the same time, IRE1 $\alpha$ plays a critical role in colonic tumorigenesis; inhibition of IRE $1 \alpha$ expression decreased the stemness of colon cancer stem cells by suppressing the production of $\beta$-catenin [23].

Although andrographolide induces ER stress in cancer cells, the activation of IRE1 $\alpha$ significantly increased CCAAT-enhancerbinding protein homologous protein $(\mathrm{CHOP})$ protein expression and induced apoptosis in colon cancer cell lines through the GRP78/IRE1/XBP1/CHOP signaling pathway (Fig. 1) [22]. The UPR sensor PERK plays roles in cell protection and apoptosis, depending on stress conditions that are difficult to differentiate in terms of cell morphology in 2D cancer cell culture. This difficulty is resolved by organoid technology due to the similarity of organoids to human organ physiology, as confirmed by the finding of a patient response to matched organoid cultures in approximately $90 \%$ of cases [24]. Simultaneously, the induction of ER stress in stem cells causes loss of self-renewal and stemness capacity in a PERK-eukaryotic initiation factor- $2 \alpha$ (eIF2 $\alpha$ )-dependent manner. Nonetheless, the inhibition of PERK-eIF $2 \alpha$ signaling resulted in stem cell accumulation in organoids [20]. An organoid study of NCI-H660 cells showed that ephrin type-B receptor 4 (EPHB4) knockdown or inhibition induced immunogenic cell death and increased the phosphorylation of eIF $2 \alpha$ and IRE $1 \alpha$, with implications for more accurate prostate cancer therapy [25].

Similarly, tumor organoids provide a truly unique opportunity to evaluate chemosensitivity differences and to investigate drug resistance mechanisms. For instance, combination therapy of arginine deprivation therapy (ADT) with canavanine triggered catastrophic ER stress via the eIF2 $\alpha$-ATF4(GADD34)-CHOP signaling pathway. Nonetheless, the same arm showed intrinsic radiation insensitivity in response to ADT alone (Fig. 1) [26]. Reduction of insulin-like growth factor type 1 receptor (IGF$1 R$ ) function was found to increase cellular stress and cytokine production by phosphorylation of eIF $2 \alpha$ to promote an aggressive tumor microenvironment in human breast cancer (Fig. 1) [27].

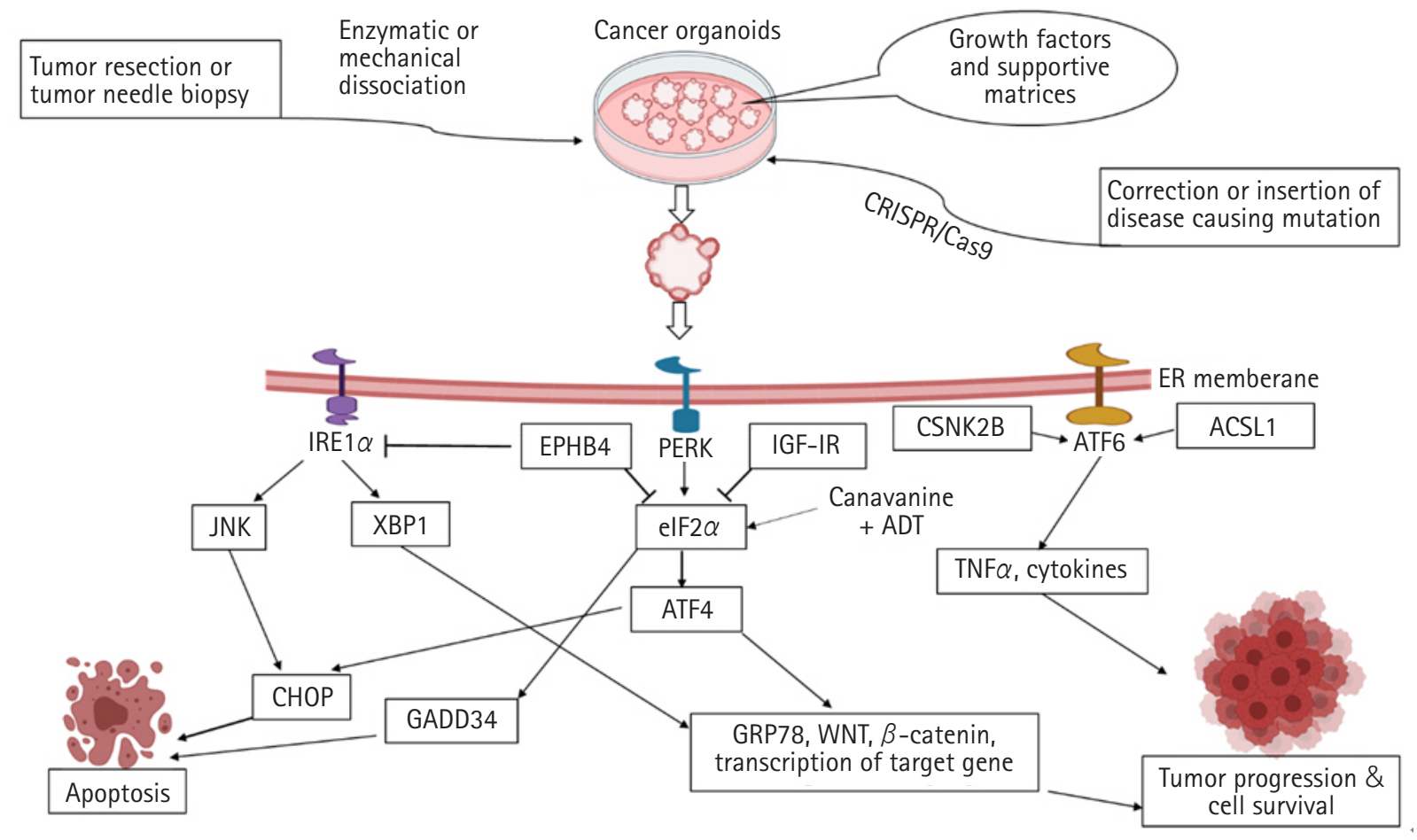

Fig. 1. Cancer organoids are developed by genetic mutations, direct tumor resection, or needle biopsy. During ER stress, the accumulation of unfolded proteins in the ER lumen activates PERK, IRE1, and ATF6, stimulating XBP1 splicing and ATF4 and ATF6 translocation in the nucleus, which are responsible for $\beta$-catenin and GRP78 upregulation. The transcription of TNF $\alpha$ and other cytokines is regulated by CSNK2B and ACSL1, and Wnt signaling activation is responsible for inflammation, cancer cell survival, and cancer progression. In contrast, IGF-IR, EPHB4 knockdown or inhibition, and ADT with canavanine combination therapy inhibit tumor progression by accelerating the ATF4 and CHOP/ GADD34 pathway. ER, endoplasmic reticulum. 
The role of cancer organoids indicates that ER stress pathways are a novel target for preclinical cancer models and may have value for treatment responses. Moreover, rearrangements in human colonic organoids and the genetic modeling of traditional serrated adenoma through the homozygous loss of adenomatous polyposis coli (APC) by the clustered regularly interspaced short palindromic repeats and CRISPR-associated 9 (CRISPR-Cas9) technique causes crypt elongation through the Wnt signaling pathway and accumulation of intestinal epithelial stem cells. However, the deletion of GRP78 (either genetically or by small molecule inhibitors of eIF $2 \alpha$ kinases) led to complete rescue, implying that the activation of ER stress poses a promising target in APC-deficient colorectal cancers (Fig. 1) [28-30]. In organoid technology, high-throughput genomic technologies have enabled identification of the most frequently mutated genes in cancer models to investigate possible therapeutic interventions [31]. Accordingly, Clarke et al. [32] demonstrated that GRP78 interaction with cleft lip and palate transmembrane 1-like (CLPTM1L), which is related to ER stress, mediated cytoprotection and chemoresistance in pancreatic adenocarcinoma. Another transcription factor involved in ER stress, ATF6, led to tumor formation in a different organ. Organoid studies have shown that excess and unresolved ER stress in intestinal epithelial cells promoted intestinal inflammation and ulcerative colitis associated with colorectal cancer through activation of ATF6 [33]. As a predictive biomarker, it has been demonstrated that high levels of activated ATF6 increased the expression of tumor necrosis factor $\alpha(\mathrm{TNF} \alpha)$ and other inflammatory cytokines in response to tunicamycin treatment in human small intestinal organoids. This led to tumor formation regulated by casein kinase 2 beta (CSNK2B) and adipose acyl-
CoA synthetase-1 (ACSL1) [34]. Inhibition of the ATF6 signaling pathway might be a strategy for drug development for inflammatory bowel diseases (Fig. 1).

\section{The unresolved role of ER stress in cancer can be overcome by organoid models}

Organoid technology shows considerable promise for improving cancer therapy to restore the impact of cancer stem cells, drug resistance, and drug toxicity, and is also a favorable framework in terms of experimental complexity. Human cell-derived organoid models assist researchers in evaluating the activity of cancer medication in a very simple, but representative way to obtain more information on compound efficacy and potency in the transition from early-stage target identification and characterization to late-stage in vivo research. For example, the precise underlying mechanisms of pristimerin (PRIS), a natural bioactive component, remain very challenging to elucidate in $2 \mathrm{D}$ culture. At the same time, patient-derived 3D lung adenocarcinoma cell culture strongly demonstrated that PRIS might induce ER stress-mediated cell death in lung cancer [35]. Furthermore, researchers face many obstacles such as growth methods, physiological accuracy, lack of vascular and neural input, and interstitial pressure while developing organoids (Fig. 2). Despite the hurdles, researchers have developed many organoids derived from normal human tissues and cancer tissues [36].

Cell-cell interactions and cell-matrix interactions change the drug response in vivo. Interestingly, these two phenomena can be conveniently visualized in organoid models, which eventually help researchers develop more specific medication to target a disease of interest $[37,38]$. For instance, dasatinib showed resistance

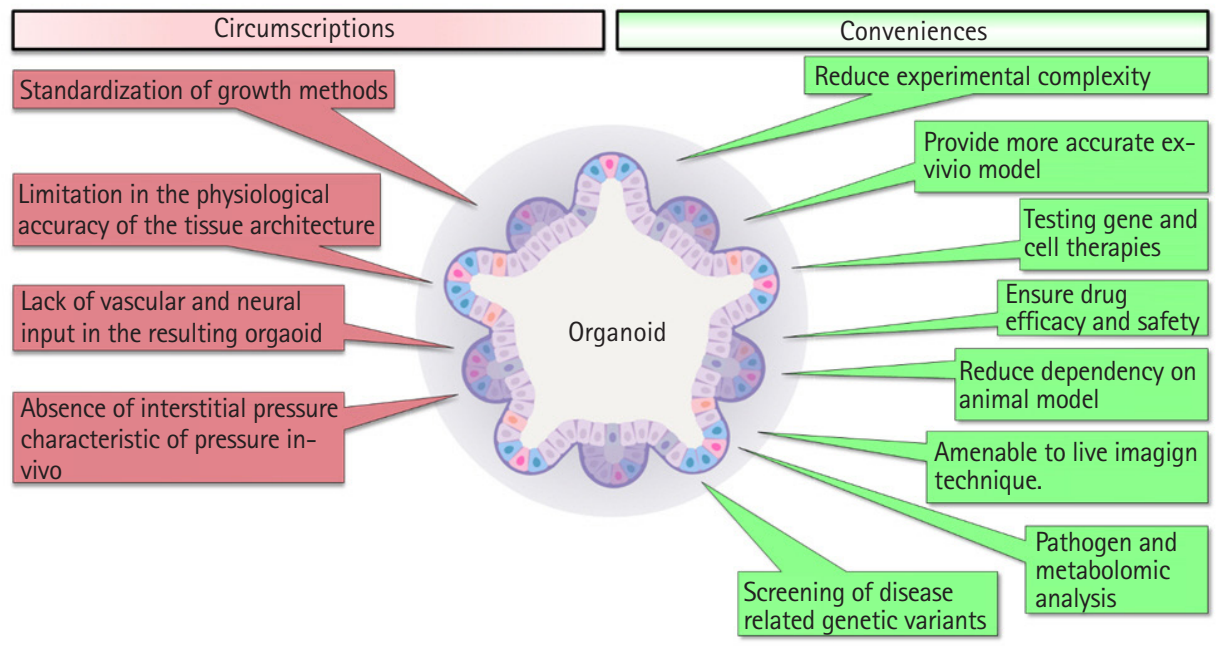

Fig. 2. Advantages and disadvantages of organoid studies. 
in recurrent ovarian cancer patients in clinical phase II studies; it appeared to be useful in $2 \mathrm{D}$ culture, but the findings in $3 \mathrm{D}$ culture resembled those found in patients [39]. Moreover, genetic modifications can be made easily in organoid models, making them more flexible for high-throughput drug screening than other in vitro methods $[36,40,41]$. In addition, the advancement of imaging techniques for visualizing organoid and protein localization in 3D culture is progressing rapidly (Fig. 2) [42].
Patient-derived organoids have flourished within the framework of personalized medicine [36].

Considering the previous evidence, scientists are becoming more enthusiastic about effective drug development by designing organoid models of ER stress. Sakatani et al. [43] used melatonin, an ATF6 inhibitor, with 5-fluorouracil (5-FU) in a patient-derived colorectal cancer organoid model and reported that melatonin could overcome 5-FU resistance, indicating its anti-cancer

Table 1. Application of organoids in the development of cancer therapeutics targeting ER stress

\begin{tabular}{|c|c|c|c|c|c|}
\hline SN & Compound name & ER & $\begin{array}{l}\text { Organoid } \\
\text { applied }\end{array}$ & Cancer & Reference \\
\hline 1 & Curcumin & $\uparrow I R E 1 \alpha$, ATF6, caspase-12 & No & Prostate, myeloma & Huang et al. [44], Rivera et al. [45] \\
\hline 2 & $\begin{array}{l}\text { Curcumin + oligomeric } \\
\text { proanthocyanidins }\end{array}$ & $\downarrow$ GRP78, HSPA5 & Yes & Colorectal & $\begin{array}{l}\text { Ravindranathan et al. [46], Toden } \\
\text { et al. [47] }\end{array}$ \\
\hline 3 & Curcumin + sildenafil & $\uparrow$ p-elF2a, CHOP & No & Gastric, colon, liver & Roberts et al. [48] \\
\hline 4 & Curcumin + irinotecan & $\uparrow \mathrm{CHOP}, \mathrm{PDI}, \mathrm{BiP}$ & No & Colorectal & Huang et al. [49] \\
\hline 5 & $\begin{array}{l}\text { Bisdemethoxycurcumin, } \\
\text { demethoxycurcumin }\end{array}$ & $\uparrow \mathrm{BiP}, \mathrm{IRE} 1 \alpha, \mathrm{CHOP}, \mathrm{ATF} 6$, caspase- 4 & Yes & Lung, colorectal & $\begin{array}{l}\text { Ko et al. [50], Wang et al. [51], } \\
\text { Yang et al. [52] }\end{array}$ \\
\hline 6 & B63 (curcumin analogue) & $\uparrow$ ER stress markers & No & Colon & Zheng et al. [53] \\
\hline 7 & B19 (curcumin analogue) & $\uparrow$ ROS, p-PERK, p-elF2 $a$, CHOP & No & Ovarian & Qu et al. [54] \\
\hline 8 & WZ35 (curcumin analogue) & $\uparrow \mathrm{p}$-elF2 $\alpha, \mathrm{CHOP}, \mathrm{ATF} 4$ & No & Breast, liver, prostate & $\begin{array}{l}\text { Wang et al. [55], Wang et al. [56], } \\
\text { Zhang et al. [57] }\end{array}$ \\
\hline 9 & MTH-3 (curcumin analogue) & $\uparrow \mathrm{CHOP}, \mathrm{ERO1}, \mathrm{PDI}, \mathrm{PERK}$ & No & Breast & Chang et al. [58] \\
\hline 10 & EGCG & $\uparrow$ Binding to BiP & No & Bladder & Luo et al. [59] \\
\hline 11 & JP8 (EGCG analogue) & $\uparrow$ ATF4, CHOP & No & Melanoma & Xie et al. [60] \\
\hline 12 & Polyphenon $\mathrm{E}^{\circledR}$ & $\uparrow \mathrm{CHOP}$ & No & Prostate & Rizzi et al. [61] \\
\hline 13 & $\gamma$-Tocotrienol & $\begin{array}{l}\uparrow \text { BiP, p-PERK, p-elF2 } \alpha, \text { ATF4, CHOP, } \\
\text { p-IRE1 } \alpha \text {, caspase-12 }\end{array}$ & No & $\begin{array}{l}\text { Breast, cervical, } \\
\text { melanoma }\end{array}$ & $\begin{array}{l}\text { Montagnani Marelli et al. [62], } \\
\text { Park et al. [63], Patacsil et al. [64] }\end{array}$ \\
\hline 14 & $\delta$-Tocotrienol & $\uparrow \mathrm{BiP}, \mathrm{CHOP}, \mathrm{PERK}$, IRE1 $\alpha$, p-elF2 $\alpha$, ATF4 & No & Melanoma & Montagnani Marelli et al. [62] \\
\hline 15 & Pimpinelol & $\uparrow$ ATF4, CHOP, GADD34 & No & Breast & Aghaei et al. [65] \\
\hline 16 & Pristimerin & $\uparrow$ ATF4, CHOP, IRE1 $\alpha$, p-elF2 $\alpha$ & Yes & Breast, lung & $\begin{array}{l}\text { Tang et al. [35], Cevatemre et al. } \\
\text { [66] }\end{array}$ \\
\hline \multirow[t]{2}{*}{17} & Cnidium officinale & $\uparrow$ ATF4, CHOP & No & Lymphoma & Cha et al. [67] \\
\hline & & $p$-elF2 $\alpha, p-P E R K$ & & & \\
\hline \multirow[t]{2}{*}{18} & Salvia miltirrhiza & $\uparrow$ ATF4, CHOP & No & Lymphoma & Kim et al. [68] \\
\hline & & $\mathrm{p}$-elF2 $\alpha, \mathrm{p}$-PERK & & & \\
\hline \multirow[t]{2}{*}{19} & Protodioscin & $\uparrow \mathrm{ATF} 4, \mathrm{CHOP}$ & No & Cervical & Lin et al. [69] \\
\hline & & p-elF2 $\alpha, p-P E R K, J N K, B i P$ & & & \\
\hline 20 & Paenia suffruticosa & $\uparrow$ DAPK3 & No & Pancreas, liver & Liu et al. [70] \\
\hline 21 & Clinacanthus nutans & $\uparrow \mathrm{IRE} 1 \alpha_{1} \mathrm{CHOP}$ & No & $\begin{array}{l}\text { Lymphoma and } \\
\text { leukemia }\end{array}$ & Lu et al. [71] \\
\hline 22 & Chrysophanol & $\uparrow$ ROS, p-PERK, p-elF2 $\alpha$, CHOP & No & Breast & Park et al. [72] \\
\hline 23 & Garlic extract & $\uparrow \mathrm{BiP}, \mathrm{MAPK}$ kinase, SKP1 & No & Myeloma, prostate & Park et al. [72] \\
\hline 24 & Ajoene & $\uparrow \mathrm{BiP}, \mathrm{CHOP}$ & No & Breast & Siyo et al. [73] \\
\hline 25 & 7-Acetylsinumaximol B & $\uparrow p$-PERK, p-elF2 $\alpha$, ATF4, CHOP, ATF6 & No & Gastric & Tsai et al. [74] \\
\hline 26 & 4-Nerolidylcatechol & $\uparrow \mathrm{p}-\mathrm{PERK}, \mathrm{IRE} 1 \alpha, \mathrm{BiP}, \mathrm{CHOP}$ & No & Melanoma & Alves-Fernandes et al. [75] \\
\hline 27 & PP-22 & $\uparrow$ PERK, CHOP, BiP, PDI & No & Nasopharyngeal & Tan et al. [76] \\
\hline 28 & Mangosteen fruit extract & $\begin{array}{l}\uparrow \text { BiP, PERK, IRE1 a calnexin, CHOP, } \\
\text { caspase- } 4\end{array}$ & No & Prostate & Li et al. [77] \\
\hline 29 & Garcinone-E & $\uparrow \mathrm{BiP}, \mathrm{IRE} 1 \alpha_{1} \mathrm{XBP} 1, \mathrm{CHOP}$, caspase-12 & No & Ovarian & Xu et al. [78] \\
\hline 30 & Gartanin & $\uparrow \mathrm{CHOP}$ & No & Prostate & Li et al. [79] \\
\hline
\end{tabular}

(Continued to the next page) 
Table 1. Continued

\begin{tabular}{|c|c|c|c|c|c|}
\hline SN & Compound name & ER & $\begin{array}{c}\text { Organoid } \\
\text { applied }\end{array}$ & Cancer & Reference \\
\hline 31 & Garcinol & $\uparrow \mathrm{CHOP}$ & No & Liver & Cheng et al. [80] \\
\hline 32 & Gambogic acid & $\uparrow \mathrm{BiP}, \mathrm{XBP} 1 \mathrm{~s}, \mathrm{CHOP}, \mathrm{GADD} 34, \mathrm{JNK}$ & Yes & Cervical, prostate & Cheng et al. [80], Pan et al. [81] \\
\hline 33 & Resveratrol & $\begin{array}{l}\uparrow \text { IRE1 } \alpha \text {, CHOP, JNK activation, ATF6a, } \\
\text { PERK, p-elF2a, BiP }\end{array}$ & No & $\begin{array}{l}\text { Myeloma, lung, } \\
\text { nasopharyngeal, } \\
\text { ovarian }\end{array}$ & $\begin{array}{l}\text { Bai et al. [82], Chow et al. [83] } \\
\text { Gwak et al. [84], Heo et al. [85] }\end{array}$ \\
\hline 34 & GSK2656157 & $\downarrow$ PERK kinase & No & Colorectal & Zheng et al. [53], Axten et al. [86] \\
\hline 35 & GSK2606414 & $\downarrow$ PERK kinase & Yes & Head and neck & McLaughlin et al. [87] \\
\hline 36 & Salubrinal & $\uparrow$ elF2 $\alpha$ & Yes & Breast, ovary, prostate & $\begin{array}{l}\text { Bastola et al. [88], Jeon et al. [89], } \\
\text { Zadra et al. [90] }\end{array}$ \\
\hline 37 & ISRIB & Inhibition of p-elF2 $\alpha$ & Yes & Prostate & Nguyen et al. [91] \\
\hline 38 & Sephin1 & Inhibition of p-elF2 $\alpha$ & Yes & Brain & Pellegrini et al. [92] \\
\hline 39 & Salicylaldimines & Inhibition of IRE1 a RNase & No & Liver & Jakku et al. [93] \\
\hline 40 & STF-083010 & Inhibition of IRE1 $a$ RNase and XBP1 & No & $\begin{array}{l}\text { Breast, pancreatic, } \\
\text { ovarian }\end{array}$ & $\begin{array}{l}\text { Barez et al. [94], Ming et al. [95], } \\
\text { Thakur et al. [96] }\end{array}$ \\
\hline 41 & MKC-3946 & Inhibition of IRE1a RNase & No & $\begin{array}{l}\text { Myeloma, pancreatic, } \\
\text { leukemia }\end{array}$ & $\begin{array}{l}\text { Lugea et al. [97], Mimura et al. [98], } \\
\text { Sun et al. [99] }\end{array}$ \\
\hline 42 & $4 \mu 8 \mathrm{C}$ & Inhibition of IRE1 $a$ RNase & Yes & Colon & Li et al. [23] \\
\hline 43 & Sunitinib & Inhibition of IRE1 a kinase & No & Pancreatic & Thakur et al. [96] \\
\hline 44 & Toyocanamycin & Inhibition of XBP1 mRNA splicing & Yes & Myeloma & Joly et al. [100], Ri et al. [101] \\
\hline 45 & $\begin{array}{l}\text { 3-Ethoxy-5,6- } \\
\text { dibromosalicylaldehyde }\end{array}$ & Inhibition of XBP1 splicing & No & Pancreatic & $\begin{array}{l}\text { Chien et al. [102], Volkmann et al. } \\
\text { [103] }\end{array}$ \\
\hline 46 & Apigenin & $\uparrow p$-IRE1 $\alpha, p$-elF2 $\alpha$, ROS & Yes & Colorectal, breast & Park et al. [104], Xu et al. [105] \\
\hline 47 & Baicalein & $\uparrow$ ATF6 & No & Liver, breast & Wang et al. [106], Yan et al. [107] \\
\hline 48 & Ceapin & Inhibitor of ATF6 & No & Liver & Torres et al. [109] \\
\hline 49 & Kaempferol & $\downarrow$ ATF6 & No & Gastric & Kim et al. [109] \\
\hline 50 & Melatonin & Inhibition of ATF6 & Yes & Colorectal & Sakatani et al. [43], Lee et al. [110] \\
\hline 51 & $16 \mathrm{~F} 16$ & PDIA3 inhibitor & No & Breast & Young et al. [111] \\
\hline 52 & ONC201 & Inhibit elF2 $\alpha$ & No & Breast & Yuan et al. [112] \\
\hline 53 & Eeyarestatin I (Eerl) & ERAD inhibitor & No & Blood & Wang et al. [113] \\
\hline
\end{tabular}

$\uparrow$, upregulation; $\downarrow$, downregulation.

ATF, activating transcription factor; BiP, CHOP, DAPK3, elF2 $\alpha$, ER, ERAD, ER01, GADD34, GRP78, HSPA5, IRE1 $\alpha$, XBP1, JNK, MAPK, PDI, PDIA3, PERK, ROS, SKP1, SN, XBP1,ER, endoplasmic reticulum.

potential. Unfortunately, the application of organoid models of ER stress for cancer drug evaluation remains insufficient despite outcomes with promising efficacy (Table 1) [44-113]. The tumor microenvironment influences the induction of ER stress or inhibition of any UPR arm. A previous report stated that the tumor microenvironment contributed to increased UPR signaling in neighboring tissues and promoted tumor development via Wnt signaling [114]. As a result, screening effective UPR-based oncotherapies by applying $2 \mathrm{D}$ cell culture models has a high probability of failure for human applications. Instead, downregulated ER stress sensors have appeared selectively in murine models of prostate tumorigenesis [115]. Consequently, organoid technology may be the only way to address differences in the UPR in cancer growth and animal models.

\section{Organoids in the development of cancer drugs targeting ER stress sensors}

The in vitro investigation of drugs using organoids opens up infinite possibilities in biomedical research. Conventionally, cancer cell proliferation, migration, and invasion are investigated via $2 \mathrm{D}$ cell culture; however, the $3 \mathrm{D}$ organoid model provides an edge to researchers for understanding the cellular and molecular mechanisms in-depth with precision [116,117]. In previous decades, tens of thousands of compounds have been screened prior to clinical trials. Despite rigorous assessments, the majority of these potential drugs (around $80 \%$ ) fail clinical trials. Effective cancer drugs are even harder to come by, with $95 \%$ or more compounds estimated to be unsuccessful at the clinical trial phase [118]. Thus, 3D organoid models are promising for effective screening of drug 
candidates, and a higher success rate can be expected.

The development of cancer drugs by targeting ER stress and the UPR pathway has become necessary for achieving effective and clinically significant outcomes. Several natural products and chemical moieties have been discovered that target ER stress and UPR arms, and these compounds have been identified as potential treatments in cancer therapy (Table 1) $[119,120]$. However, very few ER stress-targeting drug candidates have reached clinical trials (ClinicalTrials.gov) [121]. At present, only 12 naturally occurring compounds and chemical moieties have been applied in organoid models. For instance, gambogic acid is a UPR-targeted cancer therapy (Table 1) [122,123]. In 2013, Chi et al. [124] completed a phase II trial in China for advanced malignant tumors, which was not entirely successful. However, Pan et al. [81] have brought this molecule to cancer researchers' attention by applying a pancreatic cancer organoid model, and found that gambogic acid could reduce inhibit the organoid volume. In addition, drug resistance is the foremost hurdle to cancer treatment success, as cancer drugs develop resistance quickly by activating the UPR pathway [125]. For example, PERK-ATF4 activation causes 5-FU resistance in colon cancer [126]. In this case, the use of a PERK inhibitor may solve drug resistance (Table 1 ). We recommend that GSK2606414 be investigated in human trials for recovering 5-FU resistance in colon cancer because some researchers have shown acceptable results in an ex vivo organoid experiment (Table 1) [87]. In light of the various aspects of drug development targeting ER stress sensors, organoid models could play a significant role in speeding up the discovery and understanding of potential drug candidates.

\section{Conclusions}

ER stress and UPR are currently considered the most widely studied targets in the fight against cancer. Cancer cells initiate the UPR and develop drug resistance by activating the UPR sensors ATF6, IRE1 $\alpha$, and PERK and their regulator chaperone proteins. Much remains to be learned about the involvement of UPR in chemotherapy resistance. Nonetheless, it has not been possible heretofore to resolve these issues because of the plethora of conventional $2 \mathrm{D}$ cell culture models used to study the UPR and ER stress. Hopefully, patient-derived organoid models will be a blessing for cancer biologists to solve these challenging issues regarding ER stress and the UPR.

\section{Notes}

\section{Conflict of interest}

Hyung-Ryong Kim has been the president of the Organoid Society since 2018. No potential conflict of interest relevant to this article was reported..

\section{Funding}

This work was supported by the Bio \& Medical Technology Development Program (NRF-2017M3A9E4047243) of the National Research Foundation of Korea funded by the Ministry of Science and ICT, Republic of Korea.

\section{ORCID}

Hyung-Ryong Kim, https://orcid.org/0000-0002-6710-6964

\section{References}

1. Zhang G. Biomimicry in biomedical research. Organogenesis 2012;8:101-2.

2. Clevers H. Modeling development and disease with organoids. Cell 2016;165:1586-97.

3. Lou YR, Leung AW. Next generation organoids for biomedical research and applications. Biotechnol Adv 2018;36:132-49.

4. Eiraku M, Takata N, Ishibashi H, Kawada M, Sakakura E, Okuda S, et al. Self-organizing optic-cup morphogenesis in three-dimensional culture. Nature 2011;472:51-6.

5. Dye BR, Hill DR, Ferguson MA, Tsai YH, Nagy MS, Dyal R, et al. In vitro generation of human pluripotent stem cell derived lung organoids. Elife 2015;4:e05098.

6. Greggio C, De Franceschi F, Figueiredo-Larsen M, Gobaa S, Ranga A, Semb H, et al. Artificial three-dimensional niches deconstruct pancreas development in vitro. Development 2013;140:4452-62

7. Nakano T, Ando S, Takata N, Kawada M, Muguruma K, Sekiguchi K, et al. Self-formation of optic cups and storable stratified neural retina from human ESCs. Cell Stem Cell 2012; 10:771-85.

8. Tauriello DVF, Palomo-Ponce S, Stork D, Berenguer-Llergo A, Badia-Ramentol J, Iglesias $M$, et al. TGF $\beta$ drives immune evasion in genetically reconstituted colon cancer metastasis. Nature 2018;554:538-43.

9. Wimmer RA, Leopoldi A, Aichinger M, Wick N, Hantusch B, Novatchkova M, et al. Human blood vessel organoids as a model of diabetic vasculopathy. Nature 2019;565:505-10.

10. Huang N, Yu Y, Qiao J. Dual role for the unfolded protein response in the ovary: adaption and apoptosis. Protein Cell 
2017;8:14-24.

11. King AP, Wilson JJ. Endoplasmic reticulum stress: an arising target for metal-based anticancer agents. Chem Soc Rev 2020; 49:8113-36.

12. Senft D, Ronai ZA. UPR, autophagy, and mitochondria crosstalk underlies the ER stress response. Trends Biochem Sci 2015;40:141-8.

13. Madden E, Logue SE, Healy SJ, Manie S, Samali A. The role of the unfolded protein response in cancer progression: From oncogenesis to chemoresistance. Biol Cell 2019;111:1-17.

14. Avril T, Vauléon E, ChevetE. Endoplasmic reticulum stress signaling and chemotherapy resistance in solid cancers. Oncogenesis 2017;6:e373.

15. Pommier A, Anaparthy N, Memos N, Kelley ZL, Gouronnec A, Yan R, et al. Unresolved endoplasmic reticulum stress engenders immune-resistant, latent pancreatic cancer metastases. Science 2018;360:eaao4908.

16. Kato Y, Ozawa S, Miyamoto C, Maehata Y, Suzuki A, Maeda $\mathrm{T}$, et al. Acidic extracellular microenvironment and cancer. Cancer Cell Int 2013;13:89.

17. Yoshida H. ER stress and diseases. FEBS J 2007;274:630-58.

18. Lo YH, Karlsson K, Kuo CJ. Applications of organoids for cancer biology and precision medicine. Nat Cancer 2020;1:761-73.

19. Xu H, Jiao Y, Qin S, Zhao W, Chu Q, Wu K. Organoid technology in disease modelling, drug development, personalized treatment and regeneration medicine. Exp Hematol Oncol 2018; 7:30.

20. Heijmans J, van Lidth de Jeude JF, Koo BK, Rosekrans SL, Wielenga MC, van de Wetering $M$, et al. ER stress causes rapid loss of intestinal epithelial stemness through activation of the unfolded protein response. Cell Rep 2013;3:1128-39.

21. Spaan CN, Smit WL, van Lidth de Jeude JF, Meijer BJ, Muncan V, van den Brink GR, et al. Expression of UPR effector proteins ATF6 and XBP1 reduce colorectal cancer cell proliferation and stemness by activating PERK signaling. Cell Death Dis 2019;10:490.

22. Banerjee A, Ahmed H, Yang P, Czinn SJ, Blanchard TG. Endoplasmic reticulum stress and IRE-1 signaling cause apoptosis in colon cancer cells in response to andrographolide treatment. Oncotarget 2016; 7:41432-44.

23. Li XX, Zhang HS, Xu YM, Zhang RJ, Chen Y, Fan L, et al. Knockdown of IRE1 1 inhibits colonic tumorigenesis through decreasing $\beta$-catenin and IRE1 $\alpha$ targeting suppresses colon cancer cells. Oncogene 2017;36:6738-46.

24. Kim J, Koo BK, Knoblich JA. Human organoids: model systems for human biology and medicine. Nat Rev Mol Cell Biol 2020;21:571-84.

25. Sagar V, Vatapalli R, Lysy B, Pamarthy S, Anker JF, Rodriguez
Y, et al. EPHB4 inhibition activates ER stress to promote immunogenic cell death of prostate cancer cells. Cell Death Dis 2019;10:801.

26. Chen O, Manig F, Lehmann L, Sorour N, Löck S, Yu Z, et al. Dual role of ER stress in response to metabolic co-targeting and radiosensitivity in head and neck cancer cells. Cell Mol Life Sci 2020.

27. Obr AE, Kumar S, Chang YJ, Bulatowicz JJ, Barnes BJ, Birge $\mathrm{RB}$, et al. Insulin-like growth factor receptor signaling in breast tumor epithelium protects cells from endoplasmic reticulum stress and regulates the tumor microenvironment. Breast Cancer Res 2018;20:138.

28. Michels BE, Mosa MH, Grebbin BM, Yepes D, Darvishi T, Hausmann J, et al. Human colon organoids reveal distinct physiologic and oncogenic Wnt responses. J Exp Med 2019; 216:704-20.

29. Schmidt S, Gay D, Uthe FW, Denk S, Paauwe M, Matthes N, et al. A MYC-GCN2-eIF2 $\alpha$ negative feedback loop limits protein synthesis to prevent MYC-dependent apoptosis in colorectal cancer. Nat Cell Biol 2019;21:1413-24.

30. van Lidth de Jeude JF, Meijer BJ, Wielenga MCB, Spaan CN, Baan B, Rosekrans SL, et al. Induction of endoplasmic reticulum stress by deletion of Grp78 depletes Apc mutant intestinal epithelial stem cells. Oncogene 2017;36:3397-405.

31. Boretto M, Maenhoudt N, Luo X, Hennes A, Boeckx B, Bui $B$, et al. Patient-derived organoids from endometrial disease capture clinical heterogeneity and are amenable to drug screening. Nat Cell Biol 2019;21:1041-51.

32. Clarke WR, Amundadottir L, James MA. CLPTM1L/CRR9 ectodomain interaction with GRP78 at the cell surface signals for survival and chemoresistance upon ER stress in pancreatic adenocarcinoma cells. Int J Cancer 2019;144:1367-78.

33. Hanaoka M, Ishikawa T, Ishiguro M, Tokura M, Yamauchi S, Kikuchi A, et al. Expression of ATF6 as a marker of precancerous atypical change in ulcerative colitis-associated colorectal cancer: a potential role in the management of dysplasia. J Gastroenterol 2018;53:631-41.

34. Stengel ST, Fazio A, Lipinski S, Jahn MT, Aden K, Ito G, et al. Activating transcription factor 6 mediates inflammatory signals in intestinal epithelial cells upon endoplasmic reticulum stress. Gastroenterology 2020;159:1357-74.

35. Tang Y, Lei Y, Huang S, Li Z, Chen X, Luo H, et al. Pristimerin exacerbates cellular injury in conditionally reprogrammed patient-derived lung adenocarcinoma cells by aggravating mitochondrial impairment and endoplasmic reticulum stress through EphB4/CDC42/N-WASP signaling. Oxid Med Cell Longev 2020;2020:7409853. 
36. Nagle PW, Plukker JTM, Muijs CT, van Luijk P, Coppes RP. Patient-derived tumor organoids for prediction of cancer treatment response. Semin Cancer Biol 2018;53:258-64.

37. Breslin S, O'Driscoll L. Three-dimensional cell culture: the missing link in drug discovery. Drug Discov Today 2013;18: 240-9.

38. Eke I, Hehlgans S, Sandfort V, Cordes N. 3D matrix-based cell cultures: automated analysis of tumor cell survival and proliferation. Int J Oncol 2016;48:313-21.

39. Jabs J, Zickgraf FM, Park J, Wagner S, Jiang X, Jechow K, et al. Screening drug effects in patient-derived cancer cells links organoid responses to genome alterations. Mol Syst Biol 2017;13:955.

40. Driehuis E, Clevers H. CRISPR/Cas 9 genome editing and its applications in organoids. Am J Physiol Gastrointest Liver Physiol 2017;312:G257-65.

41. Zhang Z, Zhang Y, Gao F, Han S, Cheah KS, Tse HF, et al. CRISPR/Cas9 genome-editing system in human stem cells: current status and future prospects. Mol Ther Nucleic Acids 2017;9:230-41.

42. Rios AC, Clevers H. Imaging organoids: a bright future ahead. Nat Methods 2018;15:24-6.

43. Sakatani A, Sonohara F, GoelA. Melatonin-mediated downregulation of thymidylate synthase as a novel mechanism for overcoming 5-fluorouracil associated chemoresistance in colorectal cancer cells. Carcinogenesis 2019;40:422-31.

44. Huang AC, Chang CL, Yu CS, Chen PY, Yang JS, Ji BC, et al. Induction of apoptosis by curcumin in murine myelomonocytic leukemia WEHI-3 cells is mediated via endoplasmic reticulum stress and mitochondria-dependent pathways. Environ Toxicol 2013;28:255-66.

45. Rivera M, Ramos Y, Rodríguez-Valentín M, López-Acevedo S, Cubano LA, Zou J, et al. Targeting multiple pro-apoptotic signaling pathways with curcumin in prostate cancer cells. PLoS One 2017;12:e0179587.

46. Ravindranathan P, Pasham D, Balaji U, Cardenas J, Gu J, Toden S, et al. A combination of curcumin and oligomeric proanthocyanidins offer superior anti-tumorigenic properties in colorectal cancer. Sci Rep 2018;8:13869.

47. Toden S, Ravindranathan P, Gu J, Cardenas J, Yuchang M, Goel A. Oligomeric proanthocyanidins (OPCs) target cancer stemlike cells and suppress tumor organoid formation in colorectal cancer. Sci Rep 2018;8:3335.

48. Roberts JL, Poklepovic A, Booth L. Curcumin interacts with sildenafil to kill GI tumor cells via endoplasmic reticulum stress and reactive oxygen/nitrogen species. Oncotarget 2017;8: 99451-69.
49. Huang YF, Zhu DJ, Chen XW, Chen QK, Luo ZT, Liu CC, et al. Curcumin enhances the effects of irinotecan on colorectal cancer cells through the generation of reactive oxygen species and activation of the endoplasmic reticulum stress pathway. Oncotarget 2017;8:40264-75.

50. Ko YC, Lien JC, Liu HC, Hsu SC, Ji BC, Yang MD, et al. Demethoxycurcumin induces the apoptosis of human lung cancer NCI-H460 cells through the mitochondrial-dependent pathway. Oncol Rep 2015;33:2429-37.

51. Wang Y, DiSalvo M, Gunasekara DB, Dutton J, Proctor A, Lebhar MS, et al. Self-renewing monolayer of primary colonic or rectal epithelial cells. Cell Mol Gastroenterol Hepatol 2017;4:165-82.

52. Yang ST, Huang AC, Tang NY, Liu HC, Liao CL, Ji BC, et al. Bisdemethoxycurcumin-induced $S$ phase arrest through the inhibition of cyclin A and $\mathrm{E}$ and induction of apoptosis via endoplasmic reticulum stress and mitochondria-dependent pathways in human lung cancer NCI H460 cells. Environ Toxicol 2016;31:1899-908.

53. Zheng A, Li H, Wang X, Feng Z, Xu J, Cao K, et al. Anticancer effect of a curcumin derivative B63: ROS production and mitochondrial dysfunction. Curr Cancer Drug Targets 2014; 14:156-66.

54. Qu W, Xiao J, Zhang H, Chen Q, Wang Z, Shi H, et al. B19, a novel monocarbonyl analogue of curcumin, induces human ovarian cancer cell apoptosis via activation of endoplasmic reticulum stress and the autophagy signaling pathway. Int J Biol Sci 2013;9:766-77.

55. Wang L, Han L, Tao Z, Zhu Z, Han L, Yang Z, et al. The curcumin derivative WZ35 activates ROS-dependent JNK to suppress hepatocellular carcinoma metastasis. Food Funct 2018;9:2970-8.

56. Wang L, Wang C, Tao Z, Zhao L, Zhu Z, Wu W, et al. Curcumin derivative WZ35 inhibits tumor cell growth via ROS-YAPJNK signaling pathway in breast cancer. J Exp Clin Cancer Res 2019;38:460.

57. Zhang X, Chen M, Zou P, Kanchana K, Weng Q, Chen W, et al. Curcumin analog WZ35 induced cell death via ROSdependent ER stress and G2/M cell cycle arrest in human prostate cancer cells. BMC Cancer 2015;15:866.

58. Chang LC, Hsieh MT, Yang JS, Lu CC, Tsai FJ, Tsao JW, et al. Effect of bis(hydroxymethyl) alkanoate curcuminoid derivative MTH-3 on cell cycle arrest, apoptotic and autophagic pathway in triple-negative breast adenocarcinoma MDA-MB-231 cells: an in vitro study. Int J Oncol 2018; 52:67-76.

59. Luo KW, Lung WY, Luo XL, Huang WR. EGCG inhibited 
bladder cancer T24 and 5637 cell proliferation and migration via PI3K/AKT pathway. Oncotarget 2018;9:12261-72.

60. Xie J, Yun JP, Yang YN, Hua F, Zhang XW, Lin H, et al. A novel ECG analog 4-(S)-(2,4,6-trimethylthiobenzyl)epigallocatechin gallate selectively induces apoptosis of B16-F10 melanoma via activation of autophagy and ROS. Sci Rep 2017;7:42194.

61. Rizzi F, Naponelli V, Silva A, Modernelli A, Ramazzina I, Bonacini $\mathrm{M}$, et al. Polyphenon $\mathrm{E}(\mathrm{R})$, a standardized green tea extract, induces endoplasmic reticulum stress, leading to death of immortalized PNT1a cells by anoikis and tumorigenic PC3 by necroptosis. Carcinogenesis 2014;35:828-39.

62. Montagnani Marelli M, Marzagalli M, Moretti RM, Beretta G, Casati L, Comitato R, et al. Vitamin E $\delta$-tocotrienol triggers endoplasmic reticulum stress-mediated apoptosis in human melanoma cells. Sci Rep 2016;6:30502.

63. Park SK, Sanders BG, Kline K. Tocotrienols induce apoptosis in breast cancer cell lines via an endoplasmic reticulum stressdependent increase in extrinsic death receptor signaling. Breast Cancer Res Treat 2010;124:361-75.

64. Patacsil D, Tran AT, Cho YS, Suy S, Saenz F, Malyukova I, et al. Gamma-tocotrienol induced apoptosis is associated with unfolded protein response in human breast cancer cells. J Nutr Biochem 2012;23:93-100.

65. Aghaei M, Ghanadian M, Sajjadi SE, Saghafian R, Keyvanloo Shahrestanaki M. Pimpinelol, a novel atypical Sesquiterpene lactone from Pimpinella haussknechtii fruits with evaluation of endoplasmic reticulum stress in breast cancer cells. Fitoterapia 2018;129:198-202.

66. Cevatemre B, Erkısa M, Aztopal N, Karakas D, Alper P, Tsimplouli C, et al. A promising natural product, pristimerin, results in cytotoxicity against breast cancer stem cells in vitro and xenografts in vivo through apoptosis and an incomplete autopaghy in breast cancer. Pharmacol Res 2018;129:500-14.

67. Cha JA, Song HS, Kang B, Park MN, Park KS, Kim SH, et al. miR-211 plays a critical role in Cnidium officinale Makino extract-induced, ROS/ER stress-mediated apoptosis in U937 and U266 cells. Int J Mol Sci 2018; 19:865.

68. Kim C, Song HS, Park H, Kim B. Activation of ER stressdependent miR-216b has a critical role in salviamiltiorrhiza ethanol-extract-induced apoptosis in U266 and U937 cells. Int J Mol Sci 2018; 19:1240.

69. Lin CL, Lee CH, Chen CM, Cheng CW, Chen PN, Ying TH, et al. Protodioscin induces apoptosis through ROS-mediated endoplasmic reticulum stress via the JNK/p38 activation pathways in human cervical cancer cells. Cell Physiol Biochem 2018;46:322-34.
70. Liu YH, Weng YP, Tsai HY, Chen CJ, Lee DY, Hsieh CL, et al. Aqueous extracts of Paeonia suffruticosa modulates mitochondrial proteostasis by reactive oxygen species-induced endoplasmic reticulum stress in pancreatic cancer cells. Phytomedicine 2018;46:184-92.

71. Lu MC, Li TY, Hsieh YC, Hsieh PC, Chu YL. Chemical evaluation and cytotoxic mechanism investigation of Clinacanthus nutans extract in lymphoma SUP-T1 cells. Environ Toxicol 2018;33:1229-36.

72. Park S, Lim W, Song G. Chrysophanol selectively represses breast cancer cell growth by inducing reactive oxygen species production and endoplasmic reticulum stress via AKT and mitogen-activated protein kinase signal pathways. Toxicol Appl Pharmacol 2018;360:201-11.

73. Siyo V, Schäfer G, Hunter R, Grafov A, Grafova I, Nieger $\mathrm{M}$, et al. The cytotoxicity of the ajoene analogue bisPMB in WHCO1 oesophageal cancer cells is mediated by CHOP/ GADD153. Molecules 2017;22:892.

74. Tsai TC, Lai KH, Su JH, Wu YJ, Sheu JH. 7-acetylsinumaximol $\mathrm{B}$ induces apoptosis and autophagy in human gastric carcinoma cells through mitochondria dysfunction and activation of the PERK/eIF2alpha/ATF4/CHOP signaling pathway. Mar Drugs 2018;16:104.

75. Alves-Fernandes DK, Oliveira EA, Faiao-Flores F, AliceaRebecca G, Weeraratna AT, Smalley KSM, et al. ER stress promotes antitumor effects in BRAFi/MEKi resistant human melanoma induced by natural compound 4-nerolidylcathecol (4-NC). Pharmacol Res 2019;141:63-72.

76. Tan GX, Wang XN, Tang YY, Cen WJ, Li ZH, Wang GC, et al. PP-22 promotes autophagy and apoptosis in the nasopharyngeal carcinoma cell line CNE-2 by inducing endoplasmic reticulum stress, downregulating STAT3 signaling, and modulating the MAPK pathway. J Cell Physiol 2019;234:2618-30.

77. Li G, Petiwala SM, Nonn L, Johnson JJ. Inhibition of CHOP accentuates the apoptotic effect of $\alpha$-mangostin from the mangosteen fruit (Garcinia mangostana) in 22Rv1 prostate cancer cells. Biochem Biophys Res Commun 2014;453:75-80.

78. Xu XH, Liu QY, Li T, Liu JL, Chen X, Huang L, et al. Garcinone $\mathrm{E}$ induces apoptosis and inhibits migration and invasion in ovarian cancer cells. Sci Rep 2017;7:10718.

79. Li G, Petiwala SM, Yan M, Won JH, Petukhov PA, Johnson JJ. Gartanin, an isoprenylated xanthone from the mangosteen fruit (Garcinia mangostana), is an androgen receptor degradation enhancer. Mol Nutr Food Res 2016;60:1458-69.

80. Cheng AC, Tsai ML, Liu CM, Lee MF, Nagabhushanam K, Ho CT, et al. Garcinol inhibits cell growth in hepatocellular 
carcinoma Hep3B cells through induction of ROS-dependent apoptosis. Food Funct 2010;1:301-7.

81. Pan H, Lu LY, Wang XQ, Li BX, Kelly K, Lin HS. Gambogic acid induces cell apoptosis and inhibits MAPK pathway in PTEN-/-/p53-/- prostate cancer cells in vitro and ex vivo. Chin J Integr Med 2018;24:109-16.

82. Bai T, Dong DS, Pei L. Synergistic antitumor activity of resveratrol and miR-200c in human lung cancer. Oncol Rep 2014;31:2293-7.

83. Chow SE, Kao CH, Liu YT, Cheng ML, Yang YW, Huang YK, et al. Resveratrol induced ER expansion and ER caspasemediated apoptosis in human nasopharyngeal carcinoma cells. Apoptosis 2014;19:527-41.

84. Gwak H, Kim S, Dhanasekaran DN, Song YS. Resveratrol triggers ER stress-mediated apoptosis by disrupting $\mathrm{N}$-linked glycosylation of proteins in ovarian cancer cells. Cancer Lett 2016;371:347-53.

85. Heo JR, Kim SM, Hwang KA, Kang JH, Choi KC. Resveratrol induced reactive oxygen species and endoplasmic reticulum stress-mediated apoptosis, and cell cycle arrest in the A375SM malignant melanoma cell line. Int J Mol Med 2018;42:1427-35.

86. Axten JM, Romeril SP, Shu A, Ralph J, Medina JR, Feng Y, et al. Discovery of GSK2656157: an optimized PERK inhibitor selected for preclinical development. ACS Med Chem Lett 2013;4:964-8.

87. McLaughlin M, Pedersen M, Roulstone V, Bergerhoff KF, Smith HG, Whittock H, et al. The PERK inhibitor GSK2606414 enhances reovirus infection in head and neck squamous cell carcinoma via an ATF4-dependent mechanism. Mol Ther Oncolytics 2020;16:238-49.

88. Bastola P, Neums L, Schoenen FJ, Chien J. VCP inhibitors induce endoplasmic reticulum stress, cause cell cycle arrest, trigger caspase-mediated cell death and synergistically kill ovarian cancer cells in combination with Salubrinal. Mol Oncol 2016;10:1559-74.

89. Jeon YJ, Kim JH, Shin JI, Jeong M, Cho J, Lee K. Salubrinalmediated upregulation of eIF $2 \alpha$ phosphorylation increases doxorubicin sensitivity in MCF-7/ADR cells. Mol Cells 2016;39:129-35.

90. Zadra G, Ribeiro CF, Chetta P, Ho Y, Cacciatore S, Gao X, et al. Inhibition of de novo lipogenesis targets androgen receptor signaling in castration-resistant prostate cancer. Proc Natl Acad Sci U S A 2019;116:631-40.

91. Nguyen HG, Conn CS, Kye Y, Xue L, Forester CM, Cowan JE, et al. Development of a stress response therapy targeting aggressive prostate cancer. Sci Transl Med 2018;10:eaar2036.
92. Pellegrini L, Bonfio C, Chadwick J, Begum F, Skehel M, Lancaster MA. Human CNS barrier-forming organoids with cerebrospinal fluid production. Science 2020;369: eaaz5626.

93. Jakku R, Eda RR, Mirzadeh N, Telukutla SR, Vardhaman AK, Lingamallu G, et al. ( $\eta$-Arene) ruthenium(II) complexes with ferrocene-tethered salicylaldimine ligands: synthesis, characterization and anti-cancer properties. Polyhedron 2020;192:114829.

94. Barez SR, Atar AM, Aghaei M. Mechanism of inositolrequiring enzyme 1 -alpha inhibition in endoplasmic reticulum stress and apoptosis in ovarian cancer cells. J Cell Commun Signal 2020;14:403-15.

95. Ming J, Ruan S, Wang M, Ye D, Fan N, Meng Q, et al. A novel chemical, STF-083010, reverses tamoxifen-related drug resistance in breast cancer by inhibiting IRE1/XBP1. Oncotarget 2015;6:40692-703.

96. Thakur PC, Miller-Ocuin JL, Nguyen K, Matsuda R, Singhi AD, Zeh HJ, et al. Inhibition of endoplasmic-reticulum-stress-mediated autophagy enhances the effectiveness of chemotherapeutics on pancreatic cancer.J Transl Med 2018;16:190.

97. Lugea A, Gerloff A, Su HY, Xu Z, Go A, Hu C, et al. The combination of alcohol and cigarette smoke induces endoplasmic reticulum stress and cell death in pancreatic acinar cells. Gastroenterology2017;153:1674-86.

98. Mimura N, Fulciniti M, Gorgun G, Tai YT, Cirstea D, Santo $\mathrm{L}$, et al. Blockade of XBP1 splicing by inhibition of IRE1 1 is a promising therapeutic option in multiple myeloma. Blood 2012;119:5772-81.

99. Sun H, Lin DC, Guo X, Kharabi Masouleh B, Gery S, Cao Q, et al. Inhibition of IRE1 1 -driven pro-survival pathways is a promising therapeutic application in acute myeloid leukemia. Oncotarget 2016;7:18736-49.

100. Joly AL, Deepti A, Seignez A, Goloudina A, Hebrard S, Schmitt E, et al. The HSP90 inhibitor, 17AAG, protects the intestinal stem cell niche and inhibits graft versus host disease development. Oncogene 2016;35:2842-51.

101. Ri M, Tashiro E, Oikawa D, Shinjo S, Tokuda M, Yokouchi $\mathrm{Y}$, et al. Identification of toyocamycin, an agent cytotoxic for multiple myeloma cells, as a potent inhibitor of ER stressinduced XBP1 mRNA splicing. Blood Cancer J 2012;2:e79.

102. Chien W, Ding LW, Sun QY, Torres-Fernandez LA, Tan SZ, Xiao J, et al. Selective inhibition of unfolded protein response induces apoptosis in pancreatic cancer cells. Oncotarget 2014;5:4881-94.

103. Volkmann K, Lucas JL, Vuga D, Wang X, Brumm D, Stiles C, et al. Potent and selective inhibitors of the inositol-requiring enzyme 1 endoribonuclease. J Biol Chem 2011;286:12743- 
55.

104. Park S, Lim W, Bazer FW, Song G. Apigenin induces ROSdependent apoptosis and ER stress in human endometriosis cells. J Cell Physiol 2018;233:3055-65.

105. Xu M, Wang S, Song YU, Yao J, Huang K, Zhu X. Apigenin suppresses colorectal cancer cell proliferation, migration and invasion via inhibition of the Wnt/ $\beta$-catenin signaling pathway. Oncol Lett 2016;11:3075-80.

106. Wang Z, Jiang C, Chen W, Zhang G, Luo D, Cao Y, et al. Baicalein induces apoptosis and autophagy via endoplasmic reticulum stress in hepatocellular carcinoma cells. Biomed Res Int 2014;2014:732516.

107. Yan W, Ma X, Zhao X, Zhang S. Baicalein induces apoptosis and autophagy of breast cancer cells via inhibiting PI3K/ AKT pathway in vivo and vitro. Drug Des Devel Ther 2018; 12:3961-72.

108. Torres SE, Gallagher CM, Plate L, Gupta M, Liem CR, Guo $\mathrm{X}$, et al. Ceapins block the unfolded protein response sensor ATF6 $a$ by inducing a neomorphic inter-organelle tether. Elife 2019;8:e46595.

109. Kim TW, Lee SY, Kim M, Cheon C, Ko SG. Kaempferol induces autophagic cell death via IRE1-JNK-CHOP pathway and inhibition of G9a in gastric cancer cells. Cell Death Dis 2018;9:875.

110. Lee JH, Yoon YM, Han YS, Jung SK, Lee SH. Melatonin protects mesenchymal stem cells from autophagy-mediated death under ischaemic ER-stress conditions by increasing prion protein expression. Cell Prolif 2019;52:e12545.

111. Young HS, McGowan LM, Jepson KA, Adams JC. Impairment of cell adhesion and migration by inhibition of protein disulphide isomerases in three breast cancer cell lines. Biosci Rep 2020;40:BSR20193271.

112. Yuan X, Kho D, Xu J, Gajan A, Wu K, Wu GS. ONC201 activates ER stress to inhibit the growth of triple-negative breast cancer cells. Oncotarget 2017;8:21626-38.

113. Wang Q, Mora-Jensen H, Weniger MA, Perez-Galan P, Wolford C, Hai T, et al. ERAD inhibitors integrate ER stress with an epigenetic mechanism to activate $\mathrm{BH} 3$-only protein NOXA in cancer cells. Proc Natl Acad Sci U S A 2009; 106:2200-5.

114. Rodvold JJ, Chiu KT, Hiramatsu N, Nussbacher JK, Galimberti V, Mahadevan NR, et al. Intercellular transmission of the unfolded protein response promotes survival and drug resistance in cancer cells. Sci Signal 2017;10:eaah7177.
115. So AY, de la Fuente E, Walter P, Shuman M, Bernales S. The unfolded protein response during prostate cancer development. Cancer Metastasis Rev 2009;28:219-23.

116. Belair DG, Wolf CJ, Moorefield SD, Wood C, Becker C, Abbott BD. A three-dimensional organoid culture model to assess the influence of chemicals on morphogenetic fusion. Toxicol Sci 2018; 166:394-408.

117. Rodrigues T, Kundu B, Silva-Correia J, Kundu SC, Oliveira JM, Reis RL, et al. Emerging tumor spheroids technologies for 3D in vitro cancer modeling. Pharmacol Ther 2018; 184:201-11.

118. Hay M, Thomas DW, Craighead JL, Economides C, Rosenthal J. Clinical development success rates for investigational drugs. Nat Biotechnol 2014;32:40-51.

119. Limonta P, Moretti RM, Marzagalli M, Fontana F, Raimondi M, Montagnani Marelli M. Role of endoplasmic reticulum stress in the anticancer activity of natural compounds. Int J Mol Sci 2019;20:961.

120. Ojha R, Amaravadi RK. Targeting the unfolded protein response in cancer. Pharmacol Res 2017;120:258-66.

121. Almanza A, Carlesso A, Chintha C, Creedican S, Doultsinos D, Leuzzi B, et al. Endoplasmic reticulum stress signalling: from basic mechanisms to clinical applications. FEBS J 2019;286:241-78.

122. Hatami E, Jaggi M, Chauhan SC, Yallapu MM. Gambogic acid: a shining natural compound to nanomedicine for cancer therapeutics. Biochim Biophys Acta Rev Cancer 2020;1874:188381.

123. Krajarng A, Imoto M, Tashiro E, Fujimaki T, Shinjo S, Watanapokasin R. Apoptosis induction associated with the ER stress response through up-regulation of JNK in HeLa cells by gambogic acid. BMC Complement Altern Med 2015;15:26.

124. Chi Y, Zhan XK, Yu H, Xie GR, Wang ZZ, Xiao W, et al. An open-labeled, randomized, multicenter phase Ila study of gambogic acid injection for advanced malignant tumors. Chin Med J (Engl) 2013;126:1642-6.

125. Bahar E, Kim JY, Yoon H. Chemotherapy resistance explained through endoplasmic reticulum stress-dependent signaling. Cancers (Basel) 2019;11:338.

126. Shi Z, Yu X, Yuan M, Lv W, Feng T, Bai R, et al. Activation of the PERK-ATF4 pathway promotes chemo-resistance in colon cancer cells. Sci Rep 2019;9:3210. 